\title{
Training Effects Assessment and Reporting for Installations Implementing the 1996 Management Guidelines for the Red-cockaded Woodpecker (RCW) on Army Installations
}

Timothy J. Hayden

The "1996 Management Guidelines for the Redcockaded Woodpecker (RCW) on Army Installations" requires installations to summarize and report monitoring data annually to the U.S. Fish and Wildlife Service (USFWS). This document provides guidance for data summary and reporting of training effects and RCW population monitoring in compliance with this requirement. This guidance has been approved by the USFWS for incorporation into installation endangered species management plans (ESMPs) by reference or addendum. A primary objective of installation data summaries and reporting is to identify changes in RCW populations as a result of training activities under the 1996 management guidelines or other management activities. This guidance outlines data sources and parameters necessary to evaluate population trends in response to these activities. 


\section{Foreword}

This study was conducted for the Office of the Directorate of Environmental Programs) ODEP, Assistant Chief of Staff (Installation Management) under project 4A162720A896, "Environmental Quality Technology" Work Unit TDY, "Threshold Impact of Maneuver Training." The technical monitor was Dr. Victor Diersing, DAI M-ED-N.

The work was performed by the Ecological Processes Branch (CN-N) of the Installations division $(\mathrm{CN})$, Construction Engineering Research Laboratory (CERL). The CERL Principal Investigator was Timothy Hayden. Dr. Harold E. Balbach is Chief, CEERD-CN-N, and Dr. J ohn T. Bandy is Chief, CEERD-CN. The technical editor was Gloria J . Wienke, Information Technology Laboratory.

The Director of CERL is Dr. Michael J . O'Connor.

\section{DISCLAIMER}

The contents of this report are not to be used for advertising, publication, or promotional purposes. Citation of trade names does not constitute an official endorsement or approval of the use of such commercial products. All product names and trademarks cited are the property of their respective owners.

The findings of this report are not to be construed as an official Department of the Army position unless so designated by other authorized documents.

DESTROY THIS REPORT WHEN IT IS NO LONGER NEEDED. DO NOT RETURN IT TO THE ORIGINATOR. 


\section{Contents}

Foreword ............................................................................................................................... 2 2

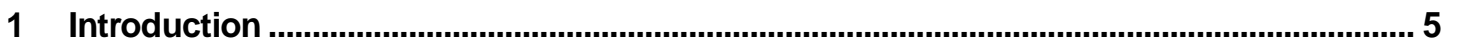

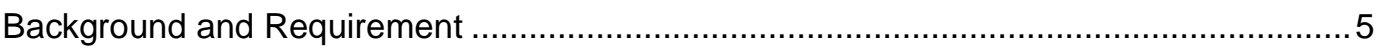

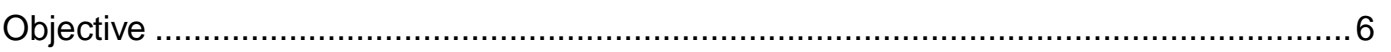

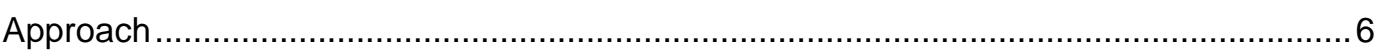

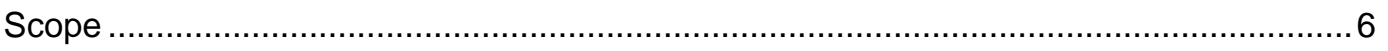

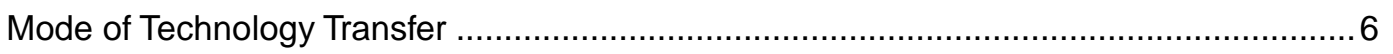

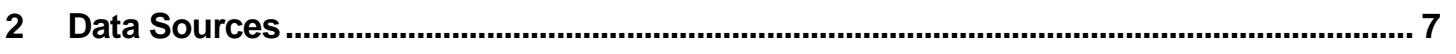

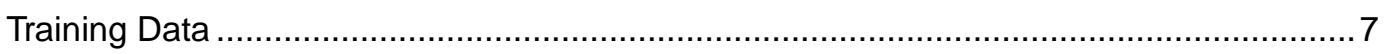

RCW Population and Habitat Data ............................................................................ 8

Other Potential Data Sources and Supplemental Research Projects.................................. 8

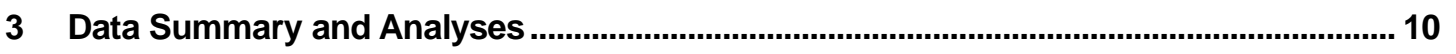

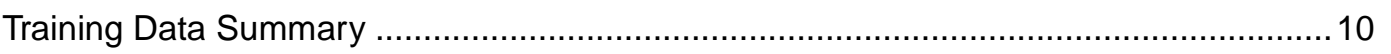

RCW Population and Habitat Data ......................................................................... 12

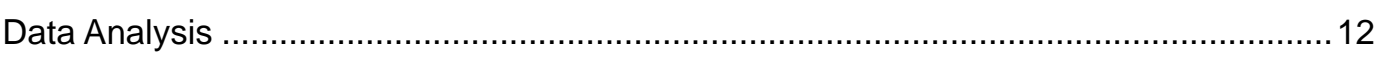

Appendix 1 ......................................................................................................................................... 16

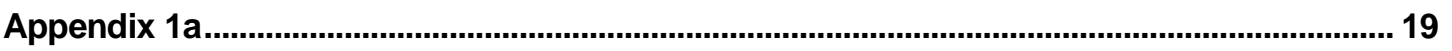

Appendix 1b................................................................................................................................... 21

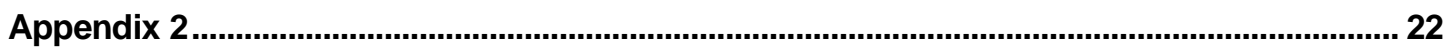

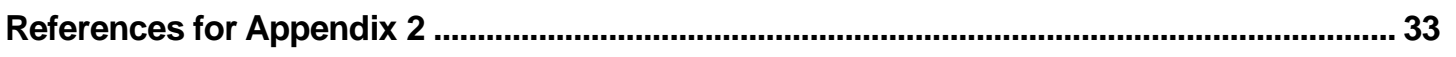

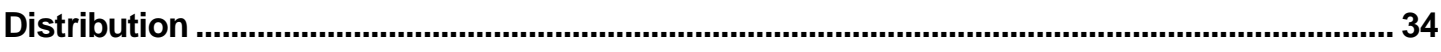

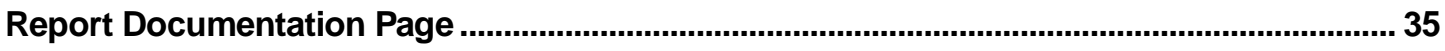





\section{Introduction}

\section{Background and Requirement}

In 1996, the U.S. Army initiated consultation with the U.S. Fish and Wildlife Service (USFWS) to implement a revised Army policy for the management of the Red-cockaded Woodpecker (Picoides borealis) on Army installations. The 1996 Management Guidelines for the Red-cockaded Woodpecker (RCW) on Army Installations and resulting biological opinion required installation natural resources and training managers, as a condition for implementation, to develop and consult (with USFWS) on individual installation endangered species management plans (ESMPs) that include enhanced monitoring and reporting requirements for training activity and effects on RCWs.

The guidelines and biological opinion require installation managers to submit an ESM P monitoring plan for peer review before implementation. As a requirement for implementing the ESMP, the installation must annually report on effects of training activity on RCW populations and habitats. Installation managers are required to report the following training data for all areas containing active and recruitment clusters:

1. Type of training that took place.

2. Duration of training.

3. Date of training.

4. Units and approximate numbers of soldiers involved in the training.

5. Approximate number and types of vehides and equipment involved in the training.

6. Other relevant information that would contribute to an understanding of the effects of military training on RCW habitat.

7. Population data for all monitored RCW clusters, including all primary and supplemental recruitment dusters.

8. An evaluation of these data for any observed trends in relation to military training and implementation of the proposed guidelines. 


\section{Objective}

The purpose of this document is to provide guidance for data summary and reporting for training and RCW population monitoring in compliance with requirements of the 1996 Management Guidelines for the Red-cockaded Woodpecker (RCW) on Army Installations (hereafter called the 1996 Management Guidelines) and USFWS biological opinion.

\section{Approach}

This guidance is based on data collection and summary requirements of the 1996 Management Guidelines. I nitial drafts of this document were reviewed by the Army Forces Command (FORSCOM) environmental engineer and representatives of installation Director of Public Works. After Army review, a draft of this guidance was provided in J anuary 1998 to the USFWS Region 4 Headquarters for independent peer review. Army and USFWS review comments were incorporated in this final guidance.

\section{Scope}

This guidance is limited to Army installations implementing the $1996 \mathrm{M}$ anage ment Guidelines for RCWs on Army installations.

\section{Mode of Technology Transfer}

For installations implementing the 1996 Management Guidelines, this guidance will be incorporated in installation ESMPs by reference or addendum. 


\section{Data Sources}

All installations implementing the 1996 Management Guidelines will submit training and population summary data to the USFWS in accordance with data fields shown in Appendix 1. These required data will be provided annually by all implementing installations during the initial 5-year implementation period of each installation's ESMP. Installations eligible to implement the 1996 Manage ment Guidelines and that currently have RCW populations include Fort Benning, Fort Bragg, Fort Gordon, Fort J ackson, Fort Polk, Fort Stewart, and Sunny Point Military Ocean Terminal.

\section{Training Data}

Installation training data will be obtained from written records and/or from the Range Facility Management Scheduling System (RFMSS). Typically, the installation G3 (Director of Plans, Training, and Mobilization) is directly responsible for maintaining range scheduling records. Installation scheduling records will provide data, by training area, on (1) type of scheduled training activity, (2) date and duration of scheduled training activity, and (3) type of unit conducting scheduled training activities.

Major Commands (MACOMs) will provide standard unit staffing and vehicle requirements for all unit types and training activity for incorporation into installation reports for USFWS. These data will be provided in the Army Training and Testing Area Carrying Capacity (ATTACC) module for the installation RFMSS. The Army is developing ATTACC to provide standard measures of training activity and to evaluate the relationship between training activity and erosion status of installations. The proponent for ATTACC is the Army Deputy Chief of Staff for Operations and Plans (DCSOPS). Although currently focused on installation erosion status, ATTACC's standardized approach to calculating training loads and impacts may in the future prove useful in reporting standard measures of training activity in relation to RCW populations and habitats. 


\section{RCW Population and Habitat Data}

The installation Natural Resource Branch, Director of Public Works (or equivalent organization element) typically is responsible for collecting population and habitat data specific to RCWs. In accordance with the Army guidelines, RCW demographic data collected include cluster activity, number of adults and fledglings, sex of birds, number of breeding groups, number of nests, and identification of color-banded birds. Habitat data required for cluster sites include density and height of hardwood encroachment, height of RCW cavities, condition of cavity trees and cavities, and assessment of any training damage.

Forestry surveys on a 10-year cycle are required under the Army guidelines to quantify availability of foraging and nesting habitat. Forest surveys typically are the responsibility of the installation Forestry Branch, Director of Public Works (or equivalent organization element).

\section{Other Potential Data Sources and Supplemental Research Projects}

Special research projects of the Department of the Army and installations will provide additional relevant information on the effects of training on RCW populations and habitats. A 3-year Army direct-funded research project initiated by the U.S. Army Construction Engineering Research Laboratory (CERL) for Fort Stewart, Georgia, will provide site-specific data on maneuver training intensity and effects on RCWs.

Another Army direct-funded research effort potentially relevant for evaluating training effects on RCWs is development of the Training Use Distribution Model (TUDM), a spatially explicit predictive model for training disturbance. Training event schedules and independent variables affecting training distribution (vegetation, roads, slope, etc.) are incorporated into the model to produce a spatially predictive model of training disturbance on an installation. This research is currently being conducted on installations in Texas, but if the models are validated, they may have applications on installations with RCWs.

Vegetation data is collected on installations as part of the Army's Integrated Training Area Management (ITAM) Program. These data may be useful when evaluating conditions in RCW foraging habitat on an annual basis.

Real-time training data will be obtained at Fort Polk from telemetered vehicles and units conducting J oint Readiness and Training Command (J RTC) exercises. 
Real-time data for vehicle and unit location are obtained remotely by electronic positioning systems. This effort is sponsored by FORSCOM. 


\section{Data Summary and Analyses}

\section{Training Data Summary}

Standard definitions for all installations will be developed and reported with concurrence of Army trainers for the following training characteristics:

1. Event type; e.g., Command Field Exercise, Field Training Exercise

2. Unit echelons (size); e.g., Battalion, Company

3. Unit type; e.g., Combat Engineer, Mechanized Infantry

The approximate number of soldiers and vehicles associated with each event type, echelon, and unit type will be reported.

The installation G3 will provide tabular summaries to USFWS of scheduled events and units by training area and dates, compiled from RFMSS and hardcopy records. These summaries will be provided for the entire year and divided for the peak RCW nesting season, March through J uly. While informative, these tabular summaries will be difficult to interpret for evaluating effects of training activity in relation to RCW populations or habitats. Totals of troops, vehicles, or training days will not likely reflect the diversity of training load and resulting effects on the landscape. For example, what is the relative training intensity or effect of a mechanized infantry company versus an armor company?

One of the objectives of the CERL training effects research is to derive a standard "index" of training load that can be tested for association with potential effects on RCW populations and habitats. The standard value(s) for training load will be based on range scheduling data. The intent is to follow as closely as possible standard training load factors being developed under ATTACC (Event Severity Factor, Vehicle Severity Factor, Vehide Conversion Factor, and Vehicle Off-road Factor). The advantages of standard training load factors and compatibility with the ATTACC approach are:

- standard units of measure for training load across training areas, among installations, and through time

- relatively straightforward independent variable(s) for analysis of effects on RCW populations and habitats 
- significantly eased data generation and reporting requirements since ATTACC factors will be incorporated in future versions of RF MSS

- comparability among installations with different training missions ( e.g., Fort Stewart - heavy mechanized versus F ort Bragg - light infantry versus Fort J ackson - TRADOC activities).

Table 1 shows event severity factors derived by ATTACC for a matrix of training event types by unit types. In this example, impact factors are normalized to a standard unit in a standard training event - in this case, an armor battalion conducting a battalion field training exercise (FTX). Note the variability in the estimated impact across unit and exercise types. This variability illustrates why a standardized index of training load is useful for analytical purposes beyond a simple tally of units or training events.

Tabular summaries of range scheduling data and derived training load factors will provide information on the variability of training intensity spatially across the installation and over time.

Table 1. ATTACC event severity factors.

\begin{tabular}{|l|c|c|c|c|c|c|c|c|}
\hline & $\begin{array}{c}\text { Armor BN } \\
\text { (M1A2) }\end{array}$ & $\begin{array}{c}\text { Mechanized } \\
\text { Infantry } \\
\text { (M2/M3) }\end{array}$ & $\begin{array}{c}\text { Division } \\
\text { Cavalry } \\
\text { Squadron }\end{array}$ & $\begin{array}{c}\text { Direct Support } \\
\text { Field Artillery } \\
\text { BN (155SP) }\end{array}$ & $\begin{array}{c}\text { Combat } \\
\text { Engineer } \\
\text { BN }\end{array}$ & $\begin{array}{c}\text { Forward } \\
\text { Support } \\
\text { BN }\end{array}$ & $\begin{array}{c}\text { Support } \\
\text { Field } \\
\text { Artillery BN BN }\end{array}$ & $\begin{array}{c}\text { Air } \\
\text { Defense } \\
\text { Artillery BN }\end{array}$ \\
\hline BN FTX & 1.00 & $\mathbf{1 . 2 3}$ & $\mathbf{1 . 2 3}$ & $\mathbf{0 . 7 0}$ & $\mathbf{1 . 5 0}$ & $\mathbf{1 . 1 5}$ & $\mathbf{0 . 4 0}$ & $\mathbf{0 . 3 0}$ \\
BN CFX & $\mathbf{0 . 3 5}$ & $\mathbf{0 . 4 3}$ & $\mathbf{0 . 4 3}$ & $\mathbf{0 . 2 5}$ & $\mathbf{0 . 5 2}$ & $\mathbf{0 . 0 0}$ & $\mathbf{0 . 1 4}$ & $\mathbf{0 . 1 1}$ \\
EN MAP/CPX/TWT & $\mathbf{0 . 0 9}$ & $\mathbf{0 . 1 1}$ & $\mathbf{0 . 1 1}$ & $\mathbf{0 . 0 6}$ & $\mathbf{0 . 1 3}$ & $\mathbf{0 . 1 1}$ & $\mathbf{0 . 0 3}$ & $\mathbf{0 . 0 3}$ \\
BN FCX & $\mathbf{0 . 2 0}$ & $\mathbf{0 . 2 5}$ & $\mathbf{0 . 2 5}$ & $\mathbf{0 . 0 0}$ & $\mathbf{0 . 1 3}$ & $\mathbf{0 . 1 3}$ & $\mathbf{0 . 0 8}$ & $\mathbf{0 . 0 6}$ \\
BN LFX & $\mathbf{0 . 7 0}$ & $\mathbf{0 . 8 8}$ & $\mathbf{0 . 8 6}$ & $\mathbf{0 . 2 5}$ & $\mathbf{1 . 0 5}$ & $\mathbf{0 . 4 6}$ & $\mathbf{0 . 2 8}$ & $\mathbf{0 . 2 1}$ \\
BN/DEPEX/ALERT & $\mathbf{0 . 0 3}$ & $\mathbf{0 . 0 3}$ & $\mathbf{0 . 0 3}$ & $\mathbf{0 . 0 2}$ & $\mathbf{0 . 0 3}$ & $\mathbf{0 . 0 3}$ & $\mathbf{0 . 0 1}$ & $\mathbf{0 . 0 1}$ \\
CO FTX & $\mathbf{0 . 2 3}$ & $\mathbf{0 . 2 7}$ & $\mathbf{0 . 2 7}$ & $\mathbf{0 . 1 6}$ & $\mathbf{0 . 3 2}$ & $\mathbf{0 . 2 7}$ & $\mathbf{0 . 0 8}$ & $\mathbf{0 . 0 7}$ \\
CO CFX & $\mathbf{0 . 0 6}$ & $\mathbf{0 . 0 7}$ & $\mathbf{0 . 0 7}$ & $\mathbf{0 . 0 4}$ & $\mathbf{0 . 0 8}$ & $\mathbf{0 . 0 0}$ & $\mathbf{0 . 0 2}$ & $\mathbf{0 . 0 2}$ \\
CO MAP/CPX/TWT & $\mathbf{0 . 0 2}$ & $\mathbf{0 . 0 3}$ & $\mathbf{0 . 0 3}$ & $\mathbf{0 . 0 2}$ & $\mathbf{0 . 0 3}$ & $\mathbf{0 . 0 3}$ & $\mathbf{0 . 0 1}$ & $\mathbf{0 . 0 1}$ \\
CO FCX & $\mathbf{0 . 0 6}$ & $\mathbf{0 . 0 7}$ & $\mathbf{0 . 0 7}$ & $\mathbf{0 . 0 4}$ & $\mathbf{0 . 0 4}$ & $\mathbf{0 . 0 4}$ & $\mathbf{0 . 0 2}$ & $\mathbf{0 . 0 2}$ \\
CO LFX & $\mathbf{0 . 1 8}$ & $\mathbf{0 . 2 2}$ & $\mathbf{0 . 2 2}$ & $\mathbf{0 . 1 3}$ & $\mathbf{0 . 2 6}$ & $\mathbf{0 . 1 4}$ & $\mathbf{0 . 0 7}$ & $\mathbf{0 . 0 5}$ \\
CO DEPEX/ALERT & $\mathbf{0 . 0 1}$ & $\mathbf{0 . 0 1}$ & $\mathbf{0 . 0 1}$ & $\mathbf{0 . 0 1}$ & $\mathbf{0 . 0 1}$ & $\mathbf{0 . 0 1}$ & $\mathbf{0 . 0 0}$ & $\mathbf{0 . 0 0}$ \\
CREW WPNS SUST & 0.01 & $\mathbf{0 . 0 1}$ & $\mathbf{0 . 0 1}$ & $\mathbf{0 . 0 1}$ & $\mathbf{0 . 0 1}$ & $\mathbf{0 . 0 1}$ & $\mathbf{0 . 0 1}$ & $\mathbf{0 . 0 0}$ \\
INDV WPNS QUAL & $\mathbf{0 . 0 1}$ & $\mathbf{0 . 0 1}$ & $\mathbf{0 . 0 1}$ & $\mathbf{0 . 0 0}$ & $\mathbf{0 . 0 1}$ & $\mathbf{0 . 0 1}$ & $\mathbf{0 . 0 0}$ & $\mathbf{0 . 0 0}$ \\
INDV COM ML TNG & 0.01 & 0.01 & 0.01 & 0.01 & 0.00 & 0.01 & 0.00 & 0.00 \\
INDV DVR TNG/MNT & 0.01 & 0.01 & 0.01 & 0.01 & 0.01 & 0.01 & 0.00 & 0.00
\end{tabular}

\footnotetext{
1 From Anderson, A., L. Chenkin, L. Winters, R.P. Hunt, C.L. Couvillon, D. McFerren, S. Sekscienski, T. Shirnia, and P. Sydleko. 1996. Army Training and Testing Area Carrying Capacity (ATTACC) and Evaluation of Land Value Study (ELVS) in 1996 Integrated Training Area Management Workshop, LaCrosse, WI, pp 8-17.
} 


\section{RCW Population and Habitat Data}

Installation natural resources managers will provide tabular summaries of RCW demographic and habitat data to USFWS. In accordance with the 1996 Management Guidelines, data summaries for monitored clusters will include number of active and inactive clusters, nest success, number of young fledged, group size, adult turnover, and recruitment. Quantitative and qualitative habitat data and observed training impacts on habitat will be summarized. Most Army installations with RCWs have mature programs for collecting, analyzing, and reporting population monitoring data. Army-level summaries will report these data in formats suitable for comparison among installations. Methods and sampling design for collection of RCW population data will be described in appropriate sections of installation ESMPs.

\section{Data Analysis}

Evaluation of training effects on RCW populations under the 1996 Management Guidelines will primarily test association between standard measures of training load and RCW demographic measures. Statistical approaches and tests will depend on specific hypotheses tested and variable type. Due to the hypotheses of primary concern and the nature of the available data, most statistical analysis will rely primarily on appropriate correlation and regression methodologies. Initial analyses will test the following general null hypotheses:

1. There is no association of standardized measures of training load with measures of RCW demographic variables - both within year and across years (as data become available).

2. There is no association of standardized measures of training load with measures or ranking of RCW habitat quality and disturbance - both within year and across years (as data become available).

3. There is no difference in RCW recruitment between supplemental recruitment clusters and primary recruitment dusters (as data become available).

4. There is no difference in RCW reproductive success and group composition between supplemental recruitment dusters (as they become active) and currently active and primary recruitment dusters.

Primary dependent variables of concern for RCW populations will include cluster activity status, measures of reproductive success, recruitment, group composition, and adult site fidelity. Independent variables will include measures of training load, management history, and habitat quality and disturbance. Time series data across years will be analyzed as these data become available in fu- 
ture years from annual monitoring programs. Incidence of observed training disturbance and habitat damage will be tested for association with measures of training load. Appropriate analyses will be performed to identify significant sources of variance in dependent variables of concern.

Type II errors (failure to detect an effect when in fact it exists) in statistical hypotheses tests are often of most concern in management of protected species. (See Steidl, Hayes, and Schauber 19972 for a recent discussion of statistical power in wildlife research.) From a conservation perspective, decisions resulting from Type II errors are more costly (potential loss of species) than incorrectly rejecting a null hypothesis (Type I error) of no effect (possibly resulting in unnecessary application of training restrictions). To increase statistical power (probability of correctly rejecting a null hypothesis that is false) to detect effects of training load on RCWs, an acceptable level of significance for rejecting null hypotheses will be alpha $=0.10$ (Type I error) for most tests. Statistical power should be presented for all tests reported to USFWS.

Table 2 shows a simulation of statistical power at alpha $=0.10$ as a function of effect size and sample size (A. Krzysik, CERL Senior Research E cologist, unpublished data). The range of effects sizes presented in Table 2 represent the majority of observed effects sizes from an analysis of 1981-90 Fort Bragg RCW population data by Mobley et al. (North Carolina State University, unpublished data). The complete results of the simulations performed by A. Krzysik are provided in Appendix 2. Installations can use these simulation results as a priori estimates of statistical power for the purpose of identifying sample size requirements for monitoring and research.

The Director of Public Works will report baseline data for RCW habitat availability from available forest surveys. Trends in forestry survey data will be evaluated locally as areas are resurveyed in future years. The Director of Training will assess changes in survey data in the context of habitat management and training loads in surveyed areas during the period between surveys.

Baseline installation monitoring programs to evaluate training effects will incorporate results of related research efforts and installation projects to evaluate the effects of military training on sensitive or protected natural

\footnotetext{
2 Steidl, R.J., J.P. Hayes, and E. Schauber. 1997. "Statistical Power Analysis in Wildlife Research." J. Wildl. Manage. $61(2): 270-279$
} 
resources. A FORSCOM-sponsored effort on Fort Polk, Louisiana, will provide information from telemetered vehicles and units that can be used to evaluate the relationship of scheduled training events to actual level of unit activity and land use in the field. CERL research on effects of maneuver training on F ort Stewart will analyze range scheduling data to quantify temporal and spatial variance of training loads. This analysis will also include an assessment of which measures or index of training activity best predict any observed effects on RCW populations or habitats. Both the Fort Polk and Fort Stewart research efforts will provide information on the probability of occurrence and duration of training activities in cluster sites under the 1996 Management Guidelines. These results will be useful in determining trends in training loads on installations over time and supplement baseline installation monitoring of training effects.

Table 2. Simulation of statistical power as a function of sample size and effect size ( $N=$ sample size, $f=$ effect size - SD between groups / SD within groups, $\alpha=0.10$ ).

\begin{tabular}{|c|c|c|c|c|c|c|c|c|}
\hline $\mathrm{N}$ & 0.30 & 0.40 & 0.50 & 0.60 & 0.70 & 0.80 & 0.90 & 1.00 \\
\hline 5 & 0.158 & 0.193 & 0.236 & 0.286 & 0.342 & 0.403 & 0.466 & 0.529 \\
\hline 10 & 0.235 & 0.330 & 0.439 & 0.553 & 0.664 & 0.761 & 0.840 & 0.900 \\
\hline 15 & 0.311 & 0.451 & 0.596 & 0.729 & 0.835 & 0.910 & 0.956 & 0.981 \\
\hline 20 & 0.383 & 0.553 & 0.714 & 0.840 & 0.923 & 0.968 & 0.989 & 0.996 \\
\hline 25 & 0.448 & 0.639 & 0.800 & 0.907 & 0.965 & 0.989 & 0.997 & 0.999 \\
\hline 30 & 0.507 & 0.711 & 0.861 & 0.948 & 0.984 & 0.996 & 0.999 & 1.000 \\
\hline 35 & 0.562 & 0.769 & 0.905 & 0.971 & 0.993 & 0.999 & 1.000 & 1.000 \\
\hline 40 & 0.611 & 0.816 & 0.936 & 0.984 & 0.997 & 0.999 & 1.000 & 1.000 \\
\hline 45 & 0.655 & 0.855 & 0.957 & 0.991 & 0.999 & 1.000 & 1.000 & 1.000 \\
\hline 50 & 0.695 & 0.886 & 0.972 & 0.995 & 0.999 & 1.000 & 1.000 & 1.000 \\
\hline 55 & 0.731 & 0.911 & 0.981 & 0.997 & 0.001 & 1.000 & 1.000 & 1.000 \\
\hline 60 & 0.763 & 0.931 & 0.988 & 0.998 & 0.001 & 1.000 & 1.000 & 1.000 \\
\hline
\end{tabular}

Simulation modeling is being performed to evaluate sensitivity of RCW populations to potential training effects on different demographic parameters. For example, activities that result in adult turnover may be more detrimental to populations than activities affecting annual reproductive success.

Assessment of RCW population trend data (biologically significant population change over time) is not necessarily a straightforward exercise. Much recent work in avian populations (note the recent literature on analysis of trends in 
breeding bird survey data, e.g., Sauer, Pendleton, and Peterjohn 19963) has attempted to evaluate appropriate methods for determining and defining biologically significant population change. Interpretation and analysis of observed population change must take into account normal environmental and demographic stochasticity, generational life span of the species, and independent factors affecting population stability such as potential military training effects. The 1996 Management Guidelines requires analysis of population trends on a 5-year cycle. Analyses of population trend data will incorporate state-of-the-art approaches in consultation with the USFWS. Army-wide reporting of standard measures of RCW population data will provide a unique opportunity to evaluate regional population trends for an endangered species.

3 Sauer, J.R., G.W. Pendleton, and B.G. Peterjohn. 1996. "Evaluating Causes of Population Change in North American Insectivorous Songbirds," Conservation Biology 7:76-86. 


\section{Appendix 1}

Red-cockaded Woodpecker (RCW) Data Update - FY

INSTALLATION:

DATE :

RCW Population:

POC:

DSN \#.

\section{A. RCW Cluster Survey and Inspection Results.}

1. Number of dusters managed

2. Number of activeclusters

a. Number of active supplemental recruitment clusters

b. Number of active clusters with training restrictions

3. Total acres of suitable acreage

4. Acres $100 \%$ surveyed for "new" RCW clusters in this FY

5. N umber of clusters inspected once per year for training impacts

a. Number of clusters checked with damage to cavity trees

b. Number of clusters checked with soil disturbance requiring remedial measures

c. Number of clusters checked with habitat disturbance requiring remedial measures

6. Number of recruitment clusters inspected twice per year for training impacts

a. Number of clusters checked with damage to cavity trees

b. Number of clusters checked with soil disturbance requiring remedial measures

c. Number of clusters checked with other habitat disturbance requiring remedial measures 


\section{B. Monitoring Results}

$\begin{array}{lll}\text { Active } & \begin{array}{l}\text { Primary } \\ \text { Recruitment }\end{array} & \begin{array}{l}\text { Supplemental } \\ \text { Recruitment }\end{array} \text { Total }\end{array}$

1. Number of clusters where monitoring was completed

1a. Number found active

1b. Number of breeding groups

1c. Number of nests found

1d. Number of cavity trees

\section{Unit Reports}

1. Number of unit reports to range control of tree damage

1a. Number of reprovisioning actions taken in response (synopsis encl osed)

2. Number of unit reports of extensive soil disturbance

2a. Number of remedial actions taken in response (synopsis enclosed)

\section{Affirmative RCW Habitat I mprovement Measures Carried Out This FY}

$\begin{array}{lll}\text { Active } & \begin{array}{l}\text { Primary } \\ \text { Recruitment }\end{array} & \begin{array}{l}\text { Supplemental } \\ \text { Recruitment }\end{array} \text { Total }\end{array}$

1. Number of cluster sites needing burning this year

1a. Number burned

2. Number of cluster sites needing midstory treatment

2a. Number treated

3. Number of foraging acres needing burning

3a. Number acres burned

4. Number of foraging acres needing midstory treatment

4a. Number acres treated

5. Number of cluster sites needing cavity restrictors 
D. Affirmative RCW Habitat I mprovement Measures Carried Out This FY (Cont'd)

\section{Primary Supplemental \\ Active Recruitment Recruitment Total}

5a. Number clusters receiving restrictors

5b. Number of cavity trees receiving

restrictors

6. Number of cavity trees

needing marking

6a. Number marked

7. Number of buffer zones

needing marking

7a. Number marked

8. Number of translocations scheduled

8a. Number of translocations received

9. Number of clusters

needing artificial cavities

9a. Number receiving inserts

9b. Number receiving drilled cavities

9c. Number receiving drilled starts

9d. Total number of cavities treated

9e. Number treated cavities with RCW use
(1) ocular sign of use
(2) confirmed roosting
(3) nesting attempted
(4) young fledged 


\title{
Appendix 1a
}

\author{
Recruitment Cluster Inspection, Monitoring \& Training Data \\ Type Recruitment Cluster: \\ Cluster Number: \\ (Primary or Supplemental)
}

A. Results of inspections and monitoring.

$\underline{\text { Yes/No }}$

Spring inspection and monitoring:

1. Visual, from ground, sign of use

2. Cavity inspected confirmed roosting

3. Nesting attempted

4. Fledged young

5. Habitat assessment/general condition:

5a. Damage to cavity or cavity start tree

5b. Soil disturbance requiring remedial measures

5c. Other habitat disturbance requiring remedial measures

6. Number of adults:

7. Number of fledglings:

8. Sex of birds: 
Fall inspection:

1. Visual, from ground, sign of use

2. Cavity inspected confirmed roosting

3. Nesting attempted

4. $\quad$ Fledged young

5. Habitat assessment/general condition:

5a. Damage to cavity or cavity start tree

5b. Soil disturbance requiring remedial measures

5c. Other habitat disturbance requiring remedial measures

\section{B. Training Data:}

Number of Unit Training Events

(Recorded at Range Control/Conducted at Recruitment Cluster location)

For each training event:

1. Date of training

2. Approximate duration of training

3. Type of training

4. Training activities (list activities conducted contained in Appendix 1)

5. Approximate number of soldiers involved

6. Approximate number and type of vehicles involved

7. Misc. 


\section{Appendix 1b}

Active Cluster Inspection \& Monitoring Data

Cluster Number:

A. Results of inspection and monitoring.

$\underline{\text { Yes/No }}$

1. Visual, from ground, sign of use

2. Cavity inspected confirmed roosting

3. Nesting attempted

4. $\quad$ Fledged young

5. Habitat assessment/general condition:

5a. Damage to cavity or cavity start tree

5b. Soil disturbance requiring remedial measures

5c. Other habitat disturbance requiring remedial measures

6. Number of adults:

7. Number of fledglings:

8. Sex of birds:

B. Training Data (if the installation has recruitment clusters):

Number of Unit Training Events

(Recorded at Range Control/Conducted at Recruitment Cluster location)

For each training event:

1. Date of training

2. Approximate duration of training

3. Type of training

4. Training activities (list activities conducted contained in Appendix 1)

5. Approximate number of soldiers involved

6. Approximate number and type of vehicles involved

7. Misc. 


\section{Appendix 2}

Summary of Red-cockaded Woodpeckers and Military Training Effects: An Evaluation of Statistical Power Requirements for Monitoring Studies

Prepared by: Anthony J . Krzysik, CERL-CN-N

\section{December 1997}

Red-cockaded Woodpecker (RCW) populations have undergone widespread and sometimes dramatic declines throughout their range over the past several decades. The major decline is attributed to the overall loss and, to a much lesser extent, the fragmentation of mature longleaf pine/wiregrass ecosystems. Local and landscape effects remain important in comprehending population spatial and temporal trends, and the management and recovery of compliance mandated populations.

While some declines remain a mystery (e.g., Baker 1983), changes in RCW preferred habitat elements are widely acknowledged as the major contributor to current population declines (Walters 1990; McFarlane 1992; Kulhavy, Hooper, and Costa 1995). Important habitat features for RCWs include the presence of reasonably large pine trees and the absence of a dense woody understory (typically scrub oaks), especially when the understory touches cavity openings in brood colonies. Longleaf pines (Pinus palustris) represent the most important cavity trees, but other pines are also used, especially loblolly (Pinus taeda). The large trees in the absence of thick understory are vital for two reasons: appropriate-sized nest cavities, and foraging surfaces for female RCWs. Females forage on large trunks below the main branches, while males forage higher in the trees, even on large branches.

Military lands in the southeastern United States possess long-term rotation forestry practices (e.g., 100-year rotation at F ort Bragg, North Carolina), and must maintain an active fire-managed ecosystems program, because high fuel loads are incompatible with the fire hazards associated with military training activities, especially on live-fire ranges. Therefore, military training lands usually contain better RCW habitat than associated private and Federal landscapes devoted to agriculture, residential development, and active forestry. 
Carter, Walters, and Doerr (1995) summarized population and demographic trends in a 12-year study of RCWs in the Sandhills of North Carolina. The study consisted of monitoring three study sites: Fort Bragg, forested residential lands, and the combination of state game lands and rural areas. Their data indicate relatively high annual fluctuations of adults at all three sites (their Figures 8 to 10), but a consistent decline over the 12-year study was evident only on the two nonmilitary study sites. An examination of their Table 2, presenting the means and ranges of percent failed nests, clutch sizes, banded nestlings fledged, and number of fledglings per successful nest, did not reveal any major data trends among the three study sites, with the exception that the Fort Bragg site had an unusually high nesting success in one year. The reasons for the high annual variability at all three study sites are intuitively challenging, because theoretically, species with a highly developed social structure and cooperative breeding should maintain stable population sizes.

A large number of potential demographic parameters can be monitored to track population trends in RCWs. Monitoring the demographic dynamics of populations is technically, statistically, and logistically exceedingly difficult in practice and typically economically unpractical. However, the colonial and cooperative characteristics of RCW populations make them reasonably easy to monitor (Walters 1990). Three demographic parameters are considered important for monitoring RCW populations (Wilcove and Simberloff 1996): (1) rate of cavity turnover, (2) combined measure of dispersal and adult mortality, and (3) rate of adult male disappearance from clusters. Nevertheless, other parameters could be added to this list.

The effect of military training activities on any demographic parameter of RCWs is unknown. Designing an experimental approach to assess directly the causeeffect of specific elements of military training in explicit spatial and temporal contexts of specific demographic parameters is statistically untenable. Resource managers may have a gut feeling that the practicality of the experimental design is limited by the replicates needed for complex ANOVAs. In reality, balanced factorial designs require surprisingly few replicates. Conceptually, the real problems are more fundamental, and can be summarized as follows:

1. Military training activities represent a complex spatial and temporal mosaic, with both spatial and temporal stochastic elements. Excluding outright habitat destruction and fragmentation, it is not known if and how military training affects RCW reproductive success or survivorship. It would be technically difficult, premature, and possibly counterproductive, to identify and isolate training elements of experimental cause-effect scenarios. An important problem to overcome 
would be the experimental representation of treatments that exactly correspond to the realities of training.

2. More thought should be given to the demographic parameters that require both short and long-term monitoring, specifically in the context of military training lands, mission activities, and the regional/global perspective.

3. On the basis of published results, there is a great deal of interyear variation in demographic parameters. This translates to the need for high statistical power for assessing trends in monitored metrics. A thorough treatment of statistical power and the dassic reference is Cohen (1988). Statistical power represents the probability of obtaining a significant difference when the difference between population means is some given value (e.g., delta). The power of an analysis is therefore related to inherent variability, sample size, and the difference between population means (delta) that you want to call a statistically significant ( $\alpha$ ) difference (Krzysik 1998). Table 2-1 provides a statistical power analysis of the Mobley, Carter, and Clarke (1996) Sandhills RCW 1981-1990 historical data set. Table 2-2 is a simulation showing the relationship of statistical power, sample size, and effect size as a function of statistical significance $(\alpha)$. Effect size is the difference between group means divided by the pooled standard deviation within groups; in other words, delta standardized by standard deviation. All analyses were performed by PC/DOS software developed by Borenstein and Cohen (1988). Figure 2-1 shows the relationship of statistical power and effect size. Statistical power can be increased by:

a. larger sample sizes,

b. stratification to reduce confounding effects (extraneous variance),

c. selecting a larger $\alpha$ (this increases the chances for a Type I error and a tendency to cond ude that control-treatment differences exist when in fact they do not, but the error is committed on the conservation side, and Type II error decreases), or

d. sel ecting a larger delta (willing to accept larger differences as being significant under any given $\alpha$ ).

4. Preliminary results indicate that sample size increases were most sensitive to levels of desired accuracy in assessing parameter trends. For example, using the typical metrics and variances of published RCW demographic parameters, and with $\alpha=0.10$, sample size (N) and accuracy have the following relationship:

\begin{tabular}{lr} 
Accuracy & \multicolumn{1}{l}{$\mathbf{N}$} \\
0.01 & 6120 \\
0.05 & 245 \\
0.10 & 61
\end{tabular}


$0.15 \quad 27$

$.20 \quad 15$

7

The above data were calculated according to Eckblad (1991) and Thompson (1992).

$$
\mathrm{N}=\mathrm{t}_{\alpha}{ }^{2} \times \operatorname{var} /(\mathrm{a} \times \mathrm{m})^{2}
$$

Where: $\quad \mathrm{N}=$ sample size, $\mathrm{t}_{\alpha}=\mathrm{t}$-table value at $\alpha$, var $=$ variance of sample data, $\mathrm{a}=$ accuracy, $\mathrm{m}=$ sample mean.

It is suggested that the monitoring of RCW demographic parameters be continued concurrently with the quantitative monitoring of military training activities under actual field conditions. The well-established but infrequently applied technique of Exploratory Data Analysis could be used with these monitoring data to guide the development of cause-effect experimental studies to assess and monitor the fundamental effects of military training activities on the survivorship and reproductive fitness of RCWs. 
Table 2-1. Statistical power analysis of the Sandhills RCW 1981-1990 historical data set.

Mobley, Carter, and Clarke (1996) evaluated the effects of different military land uses on demographic parameters of Fort Bragg RCW populations. "Treatment" groups from the study represent different military land uses including bivouac areas, weapons impact areas, drop zones, and artillery firing points. "Combined" treatment areas represent all of these military land uses combined. "Control" areas represent data from populations adjacent to F ort Bragg and RCWs on Fort Bragg that are not exposed to military land uses listed above. "f" is the effect size in the study, where $f=$ difference between group means divided by the pooled standard deviation within groups. "Alpha" $(\alpha)$ is the probability of committing a Type I error. "Power" is based on a one-tailed test and is the probability of determining a statistically significant difference between groups if one exists.

\begin{tabular}{|c|c|c|c|c|c|}
\hline Parameter & Treatment & Control & $f$ & Alpha $(\alpha)$ & Power (\%) \\
\hline \multirow[t]{9}{*}{ Clutch Size } & Combined & Fort Bragg & 0.86 & $\begin{array}{l}0.01 \\
0.05 \\
0.10 \\
0.20\end{array}$ & $\begin{array}{l}71 \\
90 \\
95 \\
98\end{array}$ \\
\hline & & Mack & 0.31 & $\begin{array}{l}0.01 \\
0.05 \\
0.10 \\
0.20\end{array}$ & $\begin{array}{l}6 \\
19 \\
31 \\
49\end{array}$ \\
\hline & & Game Lands & 0.77 & $\begin{array}{l}0.01 \\
0.05 \\
0.10 \\
0.20\end{array}$ & $\begin{array}{l}61 \\
84 \\
92 \\
97\end{array}$ \\
\hline & & SoPines & 0.30 & $\begin{array}{l}0.01 \\
0.05 \\
0.10 \\
0.20\end{array}$ & $\begin{array}{l}6 \\
17 \\
27 \\
40\end{array}$ \\
\hline & $\begin{array}{l}\text { Bivouac/Impact } \\
\text { Areas }\end{array}$ & Fort Bragg & 1.20 & 0.01 & 79 \\
\hline & & & & $\begin{array}{l}0.05 \\
0.10 \\
0.20\end{array}$ & $\begin{array}{l}94 \\
98 \\
99\end{array}$ \\
\hline & & Mack & 0.66 & $\begin{array}{l}0.01 \\
0.05 \\
0.10 \\
0.20\end{array}$ & $\begin{array}{l}17 \\
41 \\
57 \\
74\end{array}$ \\
\hline & & Game Lands & 1.07 & $\begin{array}{l}0.01 \\
0.05 \\
0.10 \\
0.20\end{array}$ & $\begin{array}{l}68 \\
89 \\
95 \\
98\end{array}$ \\
\hline & & SoPines & 0.60 & $\begin{array}{l}0.01 \\
0.05 \\
0.10 \\
0.20\end{array}$ & $\begin{array}{l}22 \\
49 \\
64 \\
79\end{array}$ \\
\hline
\end{tabular}




\begin{tabular}{|c|c|c|c|c|c|}
\hline Parameter & Treatment & Control & $f$ & Alpha $(\alpha)$ & Power (\%) \\
\hline \multirow[t]{12}{*}{ Fledgling Rate } & Combined & Fort Bragg & 0.53 & $\begin{array}{l}0.01 \\
0.05 \\
0.10 \\
0.20\end{array}$ & $\begin{array}{l}29 \\
56 \\
70 \\
84\end{array}$ \\
\hline & & Mack & 0.41 & $\begin{array}{l}0.01 \\
0.05 \\
0.10 \\
0.20\end{array}$ & $\begin{array}{l}9 \\
27 \\
41 \\
59\end{array}$ \\
\hline & & Game Lands & 0.27 & $\begin{array}{l}0.01 \\
0.05 \\
0.10 \\
0.20\end{array}$ & $\begin{array}{l}8 \\
24 \\
37 \\
54\end{array}$ \\
\hline & & SoPines & 0.45 & $\begin{array}{l}0.01 \\
0.05 \\
0.10 \\
0.20\end{array}$ & $\begin{array}{l}21 \\
46 \\
61 \\
77\end{array}$ \\
\hline & Bivouac & Fort Bragg & 0.96 & $\begin{array}{l}0.01 \\
0.05 \\
0.10 \\
0.20\end{array}$ & $\begin{array}{l}57 \\
82 \\
91 \\
97\end{array}$ \\
\hline & & Mack & 0.89 & $\begin{array}{l}0.01 \\
0.05 \\
0.10 \\
0.20\end{array}$ & $\begin{array}{l}31 \\
60 \\
75 \\
88\end{array}$ \\
\hline & & Game Lands & 0.67 & $\begin{array}{l}0.01 \\
0.05 \\
0.10 \\
0.20\end{array}$ & $\begin{array}{l}28 \\
56 \\
71 \\
85\end{array}$ \\
\hline & & SoPines & 0.84 & $\begin{array}{l}0.01 \\
0.05 \\
0.10 \\
0.20\end{array}$ & $\begin{array}{l}44 \\
73 \\
84 \\
93\end{array}$ \\
\hline & Impact & Fort Bragg & 0.61 & $\begin{array}{l}0.01 \\
0.05 \\
0.10 \\
0.20\end{array}$ & $\begin{array}{l}19 \\
45 \\
60 \\
77\end{array}$ \\
\hline & & Mack & 0.49 & $\begin{array}{l}0.01 \\
0.05 \\
0.10 \\
0.20\end{array}$ & $\begin{array}{l}8 \\
26 \\
40 \\
58\end{array}$ \\
\hline & & Game Lands & 0.24 & $\begin{array}{l}0.01 \\
0.05 \\
0.10 \\
0.20\end{array}$ & $\begin{array}{l}4 \\
15 \\
25 \\
42\end{array}$ \\
\hline & & SoPines & 0.48 & $\begin{array}{l}0.01 \\
0.05 \\
0.10 \\
0.20\end{array}$ & $\begin{array}{l}12 \\
32 \\
47 \\
65\end{array}$ \\
\hline Male Turnover & Combined & Fort Bragg & 0.75 & $\begin{array}{l}0.01 \\
0.05 \\
0.10 \\
0.20\end{array}$ & $\begin{array}{l}52 \\
78 \\
88 \\
95\end{array}$ \\
\hline
\end{tabular}




\begin{tabular}{|c|c|c|c|c|c|}
\hline Parameter & Treatment & Control & $f$ & Alpha $(\alpha)$ & Power (\%) \\
\hline & & Mack & 0.95 & $\begin{array}{l}0.01 \\
0.05 \\
0.10 \\
0.20\end{array}$ & $\begin{array}{l}46 \\
75 \\
86 \\
94\end{array}$ \\
\hline & & Game Lands & 0.70 & $\begin{array}{l}0.01 \\
0.05 \\
0.10 \\
0.20\end{array}$ & $\begin{array}{l}47 \\
75 \\
85 \\
94\end{array}$ \\
\hline & & SoPines & 0.68 & $\begin{array}{l}0.01 \\
0.05 \\
0.10 \\
0.20\end{array}$ & $\begin{array}{l}44 \\
72 \\
83 \\
93\end{array}$ \\
\hline & Bivouac & Fort Bragg & 0.78 & $\begin{array}{l}0.01 \\
0.05 \\
0.10 \\
0.20\end{array}$ & $\begin{array}{l}35 \\
64 \\
77 \\
89\end{array}$ \\
\hline & & Mack & 0.97 & $\begin{array}{l}0.01 \\
0.05 \\
0.10 \\
0.20\end{array}$ & $\begin{array}{l}35 \\
65 \\
79 \\
91\end{array}$ \\
\hline & & Game Lands & 0.73 & $\begin{array}{l}0.01 \\
0.05 \\
0.10 \\
0.20\end{array}$ & $\begin{array}{l}31 \\
60 \\
74 \\
87\end{array}$ \\
\hline & & SoPines & 0.71 & $\begin{array}{l}0.01 \\
0.05 \\
0.10 \\
0.20\end{array}$ & $\begin{array}{l}29 \\
58 \\
72 \\
86\end{array}$ \\
\hline & Impact & Fort Bragg & 0.84 & $\begin{array}{l}0.01 \\
0.05 \\
0.10 \\
0.20\end{array}$ & $\begin{array}{l}30 \\
59 \\
73 \\
87\end{array}$ \\
\hline & & Mack & 1.00 & $\begin{array}{l}0.01 \\
0.05 \\
0.10 \\
0.20\end{array}$ & $\begin{array}{l}29 \\
59 \\
74 \\
88\end{array}$ \\
\hline & & Game Lands & 0.75 & $\begin{array}{l}0.01 \\
0.05 \\
0.10 \\
0.20\end{array}$ & $\begin{array}{l}24 \\
52 \\
67 \\
82\end{array}$ \\
\hline & & SoPines & 0.72 & $\begin{array}{l}0.01 \\
0.05 \\
0.10 \\
0.20\end{array}$ & $\begin{array}{l}22 \\
49 \\
65 \\
80\end{array}$ \\
\hline \multirow[t]{2}{*}{ Female Turnover } & Combined & Fort Bragg & 0.14 & $\begin{array}{l}0.01 \\
0.05 \\
0.10 \\
0.20\end{array}$ & $\begin{array}{l}3 \\
12 \\
21 \\
36\end{array}$ \\
\hline & & Mack & 0.33 & $\begin{array}{l}0.01 \\
0.05 \\
0.10 \\
0.20\end{array}$ & $\begin{array}{l}6 \\
19 \\
31 \\
49\end{array}$ \\
\hline
\end{tabular}




\begin{tabular}{|c|c|c|c|c|c|}
\hline Parameter & Treatment & Control & $f$ & Alpha $(\alpha)$ & Power (\%) \\
\hline & & Game Lands & 0.28 & $\begin{array}{l}0.01 \\
0.05 \\
0.10 \\
0.20\end{array}$ & $\begin{array}{l}8 \\
23 \\
36 \\
54\end{array}$ \\
\hline & & SoPines & 0.17 & $\begin{array}{l}0.01 \\
0.05 \\
0.10 \\
0.20\end{array}$ & $\begin{array}{l}4 \\
14 \\
23 \\
39\end{array}$ \\
\hline & Bivouac & Fort Bragg & 0.64 & $\begin{array}{l}0.01 \\
0.05 \\
0.10 \\
0.20\end{array}$ & $\begin{array}{l}23 \\
50 \\
65 \\
81\end{array}$ \\
\hline & & Mack & 0.62 & $\begin{array}{l}0.01 \\
0.05 \\
0.10 \\
0.20\end{array}$ & $\begin{array}{l}13 \\
35 \\
50 \\
69\end{array}$ \\
\hline & & Game Lands & 0.86 & $\begin{array}{l}0.01 \\
0.05 \\
0.10 \\
0.20\end{array}$ & $\begin{array}{l}43 \\
72 \\
83 \\
93\end{array}$ \\
\hline & & SoPines & 0.58 & $\begin{array}{l}0.01 \\
0.05 \\
0.10 \\
0.20\end{array}$ & $\begin{array}{l}19 \\
44 \\
59 \\
76\end{array}$ \\
\hline & Impact & Fort Bragg & 0.23 & $\begin{array}{l}0.01 \\
0.05 \\
0.10 \\
0.20\end{array}$ & $\begin{array}{l}4 \\
14 \\
24 \\
40\end{array}$ \\
\hline & & Mack & 0.38 & $\begin{array}{l}0.01 \\
0.05 \\
0.10 \\
0.20\end{array}$ & $\begin{array}{l}5 \\
19 \\
31 \\
49\end{array}$ \\
\hline & & Game Lands & 0.34 & $\begin{array}{l}0.01 \\
0.05 \\
0.10 \\
0.20\end{array}$ & $\begin{array}{l}6 \\
21 \\
33 \\
51\end{array}$ \\
\hline & & SoPines & 0.24 & $\begin{array}{l}0.01 \\
0.05 \\
0.10 \\
0.20\end{array}$ & $\begin{array}{l}4 \\
15 \\
25 \\
42\end{array}$ \\
\hline
\end{tabular}


Table 2-2. Simulation of statistical power as a function of statistical significance ( $\alpha$ ), sample size, and effect size.

Simulations were run for $\alpha=0.01,0.05,0.10$, and $0.20 . \mathrm{N}=$ sample size, ranging from 5 to 60 . Simulations were run for effect size $0.30 \leq f \leq$ to 1.00 ( $f=$ difference between group means divided by the pooled standard deviation within groups). Range of values for $f$ were selected based on data from Mobley, Carter, and Clarke (1996). Statistical power analysis for oneway ANOVA, groups $=2$.

\begin{tabular}{|c|c|c|c|c|c|c|c|c|}
\hline \multirow[b]{2}{*}{$\alpha=0.01$} & \multicolumn{8}{|c|}{ Effect Size (f) } \\
\hline & 0.300 & 0.400 & 0.500 & 0.600 & 0.700 & 0.800 & 0.900 & 1.000 \\
\hline 5 & 0.034 & 0.038 & 0.044 & 0.052 & 0.060 & 0.070 & 0.081 & 0.093 \\
\hline 10 & 0.035 & 0.060 & 0.098 & 0.148 & 0.213 & 0.291 & 0.381 & 0.477 \\
\hline 15 & 0.056 & 0.110 & 0.190 & 0.297 & 0.423 & 0.557 & 0.685 & 0.792 \\
\hline 20 & 0.083 & 0.170 & 0.297 & 0.452 & 0.613 & 0.756 & 0.864 & 0.934 \\
\hline 25 & 0.114 & 0.237 & 0.406 & 0.591 & 0.757 & 0.877 & 0.948 & 0.982 \\
\hline 30 & 0.149 & 0.307 & 0.508 & 0.706 & 0.855 & 0.942 & 0.982 & 0.995 \\
\hline 35 & 0.185 & 0.377 & 0.601 & 0.794 & 0.917 & 0.974 & 0.994 & 0.999 \\
\hline 40 & 0.223 & 0.445 & 0.683 & 0.860 & 0.954 & 0.989 & 0.998 & 1.000 \\
\hline 45 & 0.262 & 0.510 & 0.751 & 0.907 & 0.976 & 0.995 & 0.999 & 1.000 \\
\hline 50 & 0.302 & 0.571 & 0.807 & 0.940 & 0.987 & 0.998 & 1.000 & 1.000 \\
\hline 55 & 0.341 & 0.627 & 0.852 & 0.961 & 0.993 & 0.999 & 1.000 & 1.000 \\
\hline 60 & 0.381 & 0.678 & 0.888 & 0.976 & 0.997 & 1.000 & 1.000 & 1.000 \\
\hline$\alpha=0.05$ & 0.300 & 0.400 & 0.500 & 0.600 & 0.700 & 0.800 & 0.900 & 1.000 \\
\hline 5 & 0.092 & 0.111 & 0.137 & 0.167 & 0.202 & 0.242 & 0.286 & 0.333 \\
\hline 10 & 0.136 & 0.206 & 0.294 & 0.397 & 0.507 & 0.615 & 0.715 & 0.801 \\
\hline 15 & 0.195 & 0.311 & 0.449 & 0.592 & 0.723 & 0.829 & 0.904 & 0.952 \\
\hline 20 & 0.254 & 0.411 & 0.580 & 0.735 & 0.853 & 0.930 & 0.971 & 0.990 \\
\hline 25 & 0.313 & 0.501 & 0.687 & 0.833 & 0.926 & 0.973 & 0.992 & 0.998 \\
\hline 30 & 0.370 & 0.581 & 0.770 & 0.897 & 0.964 & 0.990 & 0.998 & 0.999 \\
\hline 35 & 0.424 & 0.652 & 0.833 & 0.938 & 0.983 & 0.996 & 0.999 & 1.000 \\
\hline 40 & 0.475 & 0.712 & 0.880 & 0.964 & 0.992 & 0.999 & 1.000 & 1.000 \\
\hline 45 & 0.523 & 0.764 & 0.915 & 0.979 & 0.996 & 0.999 & 1.000 & 1.000 \\
\hline 50 & 0.568 & 0.807 & 0.941 & 0.988 & 0.998 & 1.000 & 1.000 & 1.000 \\
\hline 55 & 0.609 & 0.843 & 0.959 & 0.993 & 0.999 & 1.000 & 1.000 & 1.000 \\
\hline 60 & 0.648 & 0.874 & 0.972 & 0.996 & 1.000 & 1.000 & 1.000 & 1.000 \\
\hline$\alpha=0.10$ & 0.300 & 0.400 & 0.500 & 0.600 & 0.700 & 0.800 & 0.900 & 1.000 \\
\hline 5 & 0.158 & 0.193 & 0.236 & 0.286 & 0.342 & 0.403 & 0.466 & 0.529 \\
\hline 10 & 0.235 & 0.330 & 0.439 & 0.553 & 0.664 & 0.761 & 0.840 & 0.900 \\
\hline 15 & 0.311 & 0.451 & 0.596 & 0.729 & 0.835 & 0.910 & 0.956 & 0.981 \\
\hline
\end{tabular}




\begin{tabular}{l|llllllll}
$\mathbf{2 0}$ & 0.383 & 0.553 & 0.714 & 0.840 & 0.923 & 0.968 & 0.989 & 0.996 \\
$\mathbf{2 5}$ & 0.448 & 0.639 & 0.800 & 0.907 & 0.965 & 0.989 & 0.997 & 0.999 \\
$\mathbf{3 0}$ & 0.507 & 0.711 & 0.861 & 0.948 & 0.984 & 0.996 & 0.999 & 1.000 \\
$\mathbf{3 5}$ & 0.562 & 0.769 & 0.905 & 0.971 & 0.993 & 0.999 & 1.000 & 1.000 \\
$\mathbf{4 0}$ & 0.611 & 0.816 & 0.936 & 0.984 & 0.997 & 0.999 & 1.000 & 1.000 \\
$\mathbf{4 5}$ & 0.655 & 0.855 & 0.957 & 0.991 & 0.999 & 1.000 & 1.000 & 1.000 \\
$\mathbf{5 0}$ & 0.695 & 0.886 & 0.972 & 0.995 & 0.999 & 1.000 & 1.000 & 1.000 \\
$\mathbf{5 5}$ & 0.731 & 0.911 & 0.981 & 0.997 & 1.000 & 1.000 & 1.000 & 1.000 \\
$\mathbf{6 0}$ & 0.763 & 0.931 & 0.988 & 0.998 & 1.000 & 1.000 & 1.000 & 1.000 \\
& & & & & & & & \\
$\mathbf{\alpha}=\mathbf{0 . 2 0}$ & $\mathbf{0 . 3 0 0}$ & $\mathbf{0 . 4 0 0}$ & $\mathbf{0 . 5 0 0}$ & $\mathbf{0 . 6 0 0}$ & $\mathbf{0 . 7 0 0}$ & $\mathbf{0 . 8 0 0}$ & $\mathbf{0 . 9 0 0}$ & $\mathbf{1 . 0 0 0}$ \\
\hline $\mathbf{5}$ & 0.284 & 0.337 & 0.401 & 0.470 & 0.541 & 0.613 & 0.681 & 0.743 \\
$\mathbf{1 0}$ & 0.387 & 0.498 & 0.612 & 0.718 & 0.808 & 0.878 & 0.928 & 0.961 \\
$\mathbf{1 5}$ & 0.472 & 0.615 & 0.746 & 0.848 & 0.919 & 0.962 & 0.984 & 0.994 \\
$\mathbf{2 0}$ & 0.544 & 0.705 & 0.833 & 0.919 & 0.967 & 0.988 & 0.996 & 0.999 \\
$\mathbf{2 5}$ & 0.607 & 0.774 & 0.892 & 0.958 & 0.987 & 0.996 & 0.999 & 1.000 \\
$\mathbf{3 0}$ & 0.661 & 0.828 & 0.931 & 0.978 & 0.994 & 0.999 & 1.000 & 1.000 \\
$\mathbf{3 5}$ & 0.708 & 0.869 & 0.956 & 0.989 & 0.998 & 1.000 & 1.000 & 1.000 \\
$\mathbf{4 0}$ & 0.748 & 0.901 & 0.972 & 0.994 & 0.999 & 1.000 & 1.000 & 1.000 \\
$\mathbf{4 5}$ & 0.784 & 0.925 & 0.982 & 0.997 & 1.000 & 1.000 & 1.000 & 1.000 \\
$\mathbf{5 0}$ & 0.814 & 0.944 & 0.989 & 0.998 & 1.000 & 1.000 & 1.000 & 1.000 \\
$\mathbf{5 5}$ & 0.840 & 0.958 & 0.993 & 0.999 & 1.000 & 1.000 & 1.000 & 1.000 \\
$\mathbf{6 0}$ & 0.863 & 0.968 & 0.995 & 0.999 & 1.000 & 1.000 & 1.000 & 1.000
\end{tabular}




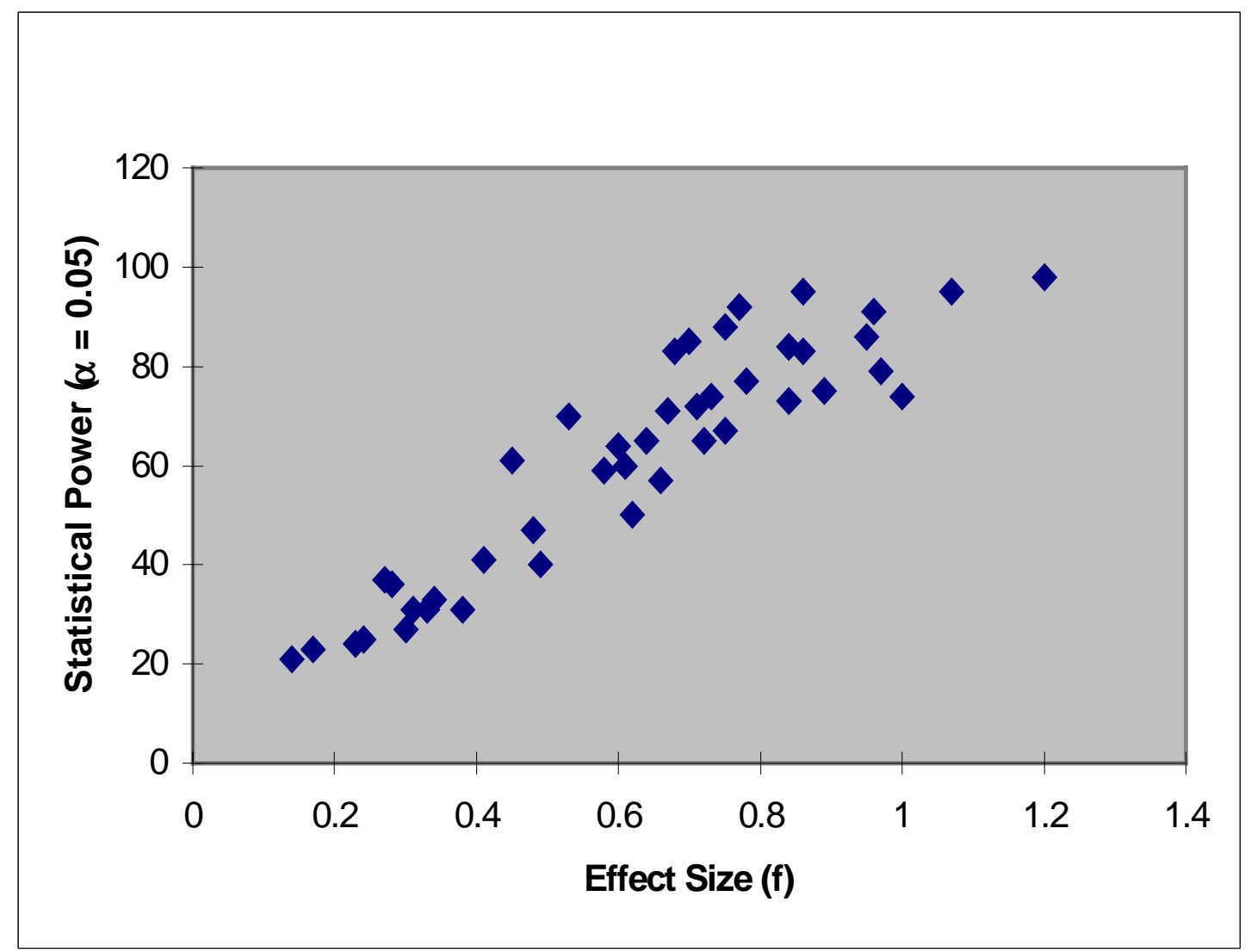

Figure 2-1. Scatter plot showing the relationship between statistical power and effect size. (Data from Table 2-1 for $\alpha=0.05$.) 


\section{References for Appendix 2}

Baker, W.W. 1983. "Dedine and extirpation of a population of red-cockaded woodpeckers in northwest Florida." Pages 44-45 in Red-cockaded Woodpecker Symposium II Proceedings, D.A. Wood, ed. Florida Game and Fresh Water Fish Commission. Tallahassee, FL.

Borenstein, M., and J . Cohen. 1988. "Statistical Power Analysis: A Computer Program." Lawrence Erlbaum Associates, Inc. Hillsdale, NJ .

Carter, J .H., III, J .R. Walters, and P.D. Doerr. 1995. "Red-cockaded woodpeckers in the North Carolina Sandhills: A 12-year population study." Pages 248-258 in Red-cockaded Woodpecker: Recovery, Ecol ogy and Management, D.L. Kulhavy, R.G. Hooper, and R. Costa, eds. Center for Applied Studies in Forestry, College of Forestry, Stephen F. Austin State University. Nacogdoches, TX.

Cohen, J . 1988. Statistical Power Analysis for the Behavioral Sciences, $2^{\text {nd }}$ ed. Lawrence Erlbaum Associates, Inc. Hillsdale, NJ .

Eckblad, J .W. 1991. "How many samples should be taken?" Bioscience 41:346-348.

Krzysik, A.J . 1998. "Ecological design and analysis: Principles and issues in environmental monitoring." In Status and Conservation of Midwestern Amphibians, M.J . Lannoo, ed. University of I owa Press. I owa City, IA.

Kulhavy, D.L., R.G. Hooper, and R. Costa, eds. 1995. Red-cockaded Woodpecker: Recovery, Ecology and Management. Center for Applied Studies in Forestry, College of Forestry, Stephen F. Austin State University. Nacogdoches, TX.

McF arlane, R.W. 1992. A Stillness in the Pines: The Ecol ogy of the Red-cockaded Woodpecker. W.W. Norton \& Company. New York, NY.

Mobley, J ., J .H. Carter, and A.L. Clarke. 1996. "Evaluation of the potential impacts of military training activity on red-cockaded woodpecker (Picoides boreal is) on Fort Bragg, North Carolina." Unpublished Report to CERL under Research Work Order \#35. 20pp.

Thompson, S.K. 1992. Sampling. J ohn Wiley \& Sons. New York, NY.

Walters, J .R. 1990. "Red-cockaded woodpeckers: A 'primitive' cooperative breeder." Pages 69-101 in Cooperative Breeding in Birds: Long-Term Studies of E col ogy and Behavior, P.B. Stacey and W.D. Koenig, eds. Cambridge University Press. New York, NY.

Wilcove, D.S., and D. Simberloff. 1996. Letter from Environmental Defense F und to Ms. J amie Clark, Assistant Director, Ecological Services, U.S. Fish and Wildlife Service, Washington, DC, 20 September 1996. 3pp. 


\title{
DISTRIBUTION
}

\author{
Chief of Engineers \\ ATTN: CEHEC-IM-LH (2) \\ ATTN: HECSA Mailroom (2) \\ ATTN: CECC-R \\ ATTN: CERD-L \\ ATTN: CERD-M \\ ACS(IM) \\ ATTN: DAIM-ED-N (2) \\ FORSCOM Installations \\ Fort Polk 71459 \\ ATTN: AFZX-PW \\ Fort Bragg 28307 \\ ATTN: AFZA-DPW \\ Fort Stewart 31314 \\ ATTN: AFZP-DE \\ TRADOC Installations \\ Fort Benning 31905 \\ ATTN: ATZB-PW \\ Fort Gordon 30905 \\ ATTN: ATZH-DI \\ Fort Jackson 29207 \\ ATTN: ATZJ-PW
}

Defense Tech Info Center 22304

ATTN: DTIC-O (2) 
Public reporting burden for this collection of information is estimated to average 1 hour per response, including the time for reviewing instructions, searching existing data sources, gathering and maintaining the data needed, and completing and reviewing the collection of information. Send comments regarding this burden estimate or any other aspect of this collection of Information, including suggestions for reducing this burden, to Washington Headquarters Services, Directorate for information Operations and Reports, 1215 Jefferson Davis Highway, Suite 1204, Arlington, VA 22202-4302, and to the Office of Management and Budget, Paperwork Reduction Project (0704-0188), Washington, DC 20503.
1. AGENCY USE ONLY (Leave Blank)
2. REPORT DATE
December 1999
3. REPORT TYPE AND DATES COVERED
Final

4. TITLE AND SUBTITLE

Training Effects Assessment and Reporting for Installations Implementing the "1996

Management Guidelines for the Red-cockaded Woodpecker (RCW) on Army

Installations"

6. AUTHOR(S)

Timothy J. Hayden

7. PERFORMING ORGANIZATION NAME(S) AND ADDRESS(ES)

U.S. Army Construction Engineering Research Laboratory (CERL)

P.O. Box 9005

Champaign, IL 61826-9005

8. PEFORMING ORGANIZATION

REPORT NUMBER

4A162720A896

TDY

TR 99/107

9. SPONSORING / MONITORING AGENCY NAME(S) AND ADDRESS(ES)

Headquarters, Department of the Army

10. SPONSORING / MONITORING

AGENCY REPORT NUMBER

ATTN: DAIM-ED-N

ACS(IM)

600 Army Pentagon

Washington, DC 20310-0600

9. SUPPLEMENTARY NOTES

Copies are available from the National Technical Information Service, 5385 Port Royal Road, Springfield, VA 22161

12a. DISTRIBUTION / AVAILABILITY STATEMENT

12b.DISTRIBUTION CODE

Approved for public release; distribution is unlimited.

13. ABSTRACT (Maximum 200 words)

The "1996 Management Guidelines for the Red-cockaded Woodpecker (RCW) on Army Installations" requires installations to summarize and report monitoring data annually to the U.S. Fish and Wildlife Service (USFWS). This document provides guidance for data summary and reporting of training effects and RCW population monitoring in compliance with this requirement. This guidance has been approved by the USFWS for incorporation into installation endangered species management plans (ESMPs) by reference or addendum. A primary objective of installation data summaries and reporting is to identify changes in RCW populations as a result of training activities under the 1996 management guidelines or other management activities. This guidance outlines data sources and parameters necessary to evaluate population trends in response to these activities.

14. SUBJECT TERMS

bird populations natural resource management Red-cockaded Woodpecker

17. SECURITY CLASSIFICATION OF REPORT

Unclassified military training

land management

threatened and endangered species
18. SECURITY CLASSIFICATION OF THIS PAGE

Unclassified
19. SECURITY CLASSIFICATION OF ASTRACT

Unclassified
15. NUMBER OF PAGES 36

16. PRICE CODE

20. LIMITATION OF ABSTRACT SAR 